\title{
Ideological Determinants of the Current Saudi-Iranian Rivalry in the Middle East
}

\begin{abstract}
The Saudi-Iranian rivalry reached a dramatic climax at the very beginning of January 2016. Unodoubtedly, Iran and Saudi Arabia represent two distinct political systems and two different approaches to foreign policy making. The question is, however, what are the reasons for these differences. It is a well-known fact that both Iranian and Saudi political systems are based on Islamic values. Yet the main difference is that their main principles stem from two divergent interpretations of Islam.

The main aim of the article is to point up the main ideological differences between Iran and Saudi Arabia which directly or indirectly shape their foreign policies. Do they play a decisive role as far as the current tensions between Iran and Saudi Arabia are concerned? As far as sources are concerned, the analysis is based on official documents issued by Ministries of Foreign Affairs of Iran and Saudi Arabia as well as selected monographs and academic articles.
\end{abstract}

Key words: Iran, Saudi Arabia, the Syrian war, religious ideology, the Islamic State

\section{Introduction}

B oth Iran and Saudi Arabia play very important roles in the Middle East. And their authorities have their strategies and regional aims. As a result, both states have competed for regional hegemony since the end of 1970's. The Saudi-Iranian rivalry reached a dramatic climax at the very beginning of January 2016. A few incidents, including the execution of a prominent Shia cleric, Nimr al-Nimr, in Saudi Arabia and the attack on the Saudi embassy in Tehran, had put a strain on bilateral relations and soon after resulted in a complete severance of diplomatic links between Riyadh and Tehran. Yoel Guzansky emphasizes the fact that "relations between Saudi Arabia and Iran are characterized by religious-ideological antagonism and competition for regional influence. One of the results of the current turmoil in the Middle East is that the hostility between the two states and their struggle over the character of the region has sharpened and intensified" (Guzansky, 2015, p. 42). At the moment Syria, Iraq, and Yemen are three main areas of this rivalry.

Unodoubtedly, Iran and Saudi Arabia represent two distinct political systems and two different approaches to foreign policy making. The question is, however, what are the reasons for these differences. It is a well-known fact that both Iranian and Saudi political systems are based on Islamic values. Yet the main difference is that their main principles stem from two divergent interpretations of Islam. While political thought in Saudi Arabia is dominated by Sunni doctrines, the Iranian is mainly Shia. Among the most important political differences one can distinguish the following:

- historical experience; 
- social attitudes to power and rulers;

- legitimization and source of power of key policy makers especially kings in Saudi Arabia and supreme leaders in Iran;

- sense of political greatness and unique nature especially related to places of worship and the right to represent the whole Islamic community;

- eventual policy aims;

- social hierarchy and organization.

In the opinion of Simon Mabon, ,the place of religion within the fabric of each state is undeniable, notably stemming from the 1979 revolution and the emergence of an Iranian theocracy, coupled with the position of Wahhabism within the Saudi state. In addition, both Saudi Arabia and Iran have sought to export their Islamic beliefs across both Gulf and wider Middle East regions" (Mabon, 2013, p. 111). As regards that, both countries use various means in order to achieve their political and economic aims, however, in most of cases they refer to ideology especially to religious values and precepts in order to justify undertaken actions. Undoubtedly, this way they intend to gain and enjoy widespread political support of either Sunnis or Shiites in the Middle East North Africa region.

According to Lawrence Rubin, in the 1990's, “Saudi Arabia perceived Iran's steps to reassert and reintegrate itself in a pragmatic manner as an indirect ideational threat. Iran's reinvention of its Islamically oriented foreign policy through its support for Islamic movements, Islamic causes, international institutions, and the conduct of its foreign relations with other states were symbolic acts to compete for leadership of the Islamic world" (Rubin, 2014, p. 101). As regards that, the situation has not changed since then. Nowadays, their spheres of influence 'under dispute' include Yemen, Lebanon, Iraq, and Syria. In all four states Iran and Saudi Arabia compete for power and try to secure influence on various ethnic or sectarian groups. What's more, both regional powers have tried to take advantage of the political turmoil in the region since 2010 .

The main aim of the article is to point up the main ideological differences between Iran and Saudi Arabia which directly or indirectly shape their foreign policies. Do they play a decisive role as far as the current tensions between Iran and Saudi Arabia are concerned? As far as sources are concerned, the analysis is based on official documents issued by Ministries of Foreign Affairs of Iran and Saudi Arabia as well as selected monographs and academic articles.

\section{Ideology as a Key Element of the Saudi Foreign Policy}

The Saudi foreign policy is based on four pillars. Firstly, Islam and its key provisions form the basis of the Saudi politics. It is enough to visit the website of the Ministry of Foreign Affairs of the Kingdom of Saudi Arabia to learn that it "derives its core values from the Islamic social and professional principles as a key element in its organizational philosophy, and inculcate the values in employees and organizational units at all levels" (Ministry's Vision, 2016). Yet some of them are rather universal and not limited to stereotypical image of Islam and its core values. Among these key provisions of the Saudi foreign policy are: 
- "loyalty to God and then the King";

- morality;

- openness and tolerance for representatives of other cultures and religions;

- transparency;

- creativity (Ministry's Vision, 2016).

As regards that, Robert Lacey points out a very interesting paradox related to this pillar - "an ancient religion defines a modern state" (Lacey, 2009, p. 10). Secondly, Saudi Arabia pictures itself as a protector as well as the most important representative of Sunni Muslims in the region. This approach is both symbolic and material as Saudi Arabia is the guardian of the holy shrines in Mecca and Medina. Saudi kings are called officially custodians of the two Holy Mosques. Thirdly, it tries to control decision-making processes within three most important international organizations dominated by Muslims, namely the Arab League, the Organization of Islamic Cooperation, and the Gulf Cooperation Council. Besides, the kingdom also plays a very important role in OPEC. Fourthly, Saudi Arabia promotes regional stability based on its hegemony. In the opinion of Tom Landsford, Saudi Arabia "has pursued moderate, pro-Western foreign policy and endeavored to contain both Iraq and Iran from becoming regional hegemons" (Landsford, 2009, pp. 173-175). These two states are dominated by Shia Muslims and therefore pose an ideological threat to Saudi interests in the region.

There is also another important ideological element, namely wahhabism. This ideology is based on ideas of Muhammad ibn Abd al-Wahhab who lived in the eighteenth century. He promoted a very strict and simple way of life. Yet the most important observation with regard to politics is connected with his clearly anti-Turkish and anti-Persian rhetoric (Małachowski, 2011, p. 14). Wahhab underlined the need for the Arab unity and suggested that only Arabs should enjoy equal rights. This way he downgraded social status of Turks or Persians. As there are many followers of Wahhab in Saudi Arabia, his ideas indirectly affect the Saudi foreign policy especially vis-à-vis Iranians.

The King's position in the Saudi political system is also worth of particular attention. Undoubtedly, he is the supreme political figure, however, he lacks any religious associations like the Supreme Leader in Iran. In other words, the King can do absolutely everything, yet the unique position of the House of Saud is a result of social and ethnic rivalry in the past. Joshua Teitelbaum points out another interesting factor related to the Saudi foreign policy. It is connected with a problem of generational change within the House of Saud. The leadership model is strictly hierarchical like in most of monarchies worldwide, however, given the number of potential heirs belonging to the same generation it determines the age of future kings. "King Fahd, who he had not functioned as a monarch since suffering a stroke in 1995, died in August 2005 at approximately 84" (Teitelbaum, 2005, p. 135). King Abdullah bin Abdulaziz Al Saud had been 81 when he had come to power and his successor, King Salman, was 80 years old in 2015. In the same year the current Crown Prince, Muhammad bin Nayef, was just 57 years old, so he was relatively young.

The Saudi foreign policy decision making is also closely linked to local tribalism. "Across the societies of the Arabian Peninsula, tribalism remains one of the strongest forces, and its consequences for the region's foreign relations should not be overlooked. Tribal identity is deeply rooted in the region's heritage and history and is often manipu- 
lated by the regional leaders for purposes of political legitimacy" (Wright, 2011, p. 83). Undoubtedly, the king has to or at least should reach a kind of compromise with most of local tribes in case of the most significant decisions related to foreign policy. This way he can secure his rule as well as meet expectations of most of citizens.

It is not a surprise that Iran plays a vital role in the framework of every Saudi strategy. As the former head of Saudi intelligence Turki al Faisal Aziz al Saud put it, "Saudi Arabia has two other concerns about Iran. First, it is in our interest that the Iranian leadership does not develop a nuclear weapon, for their doing so will make nuclear-arms proliferation in the Middle East the norm. [...] The other concern we need to address in the coming decade is the Iranian leadership's meddling and destabilizing efforts in the countries with Shia majorities, Iraq and Bahrain, as well as those countries with significant minority Shia communities, such as Kuwait, Lebanon and Yemen" (Al Faisal, 2013, p. 38). The Syrian conflict is also a good example of such concern. Saudis perceive Iran's role in the war as an attempt to expand its sphere of influence in order to become the regional hegemon (Akbarzadeh, Conduit, 2016, p. 3).

It has to be underlined that the Arab states in the Persian Gulf region except for Qatar usually follow Saudi Arabia and support its foreign policy both in the region and worldwide. "Other members of the GCC commonly bandwagon alongside Saudi Arabia (or other international powers) in order to maximize their positions within the regional or international system on issues where there is a convergence of interests" (Wright, 2011, p. 88). Such circumstances help to preserve the regional balance which seems to be one of the main principles as far as the Saudi foreign policy is concerned. The problem is Saudis are concerned with the current regional policy of Iran and accuse its authorities of actions aiming at the change of status quo in the Middle East in general and in the Persian Gulf basin in particular. No doubt their attitude is based on simple assumptions related to the Iranian ideology which plays a vital role in this case. The question is, however, if these assumptions are correct.

\section{The Main Principles of Foreign Policy of the Islamic Republic of Iran}

The Iranian statehood is one of those significant features that distinguish Iran from the Arab states in the Persian Gulf, including Saudi Arabia. Mohammad Reza Djalili and Thierry Kellner quite rightly underline that "what explains the stability of Iran is the long-term presence of the state. Unlike most of its neighbors, the Iranian state is not a new creation and does not suffer from the fragility that is sometimes seen in recently created states" (Djalili, Kellner, 2015, p. 384).

As long as Mohammad Reza Pahlavi was the Shah of Iran, Iran was an ally country of the United States and did not intend to challenge Saudi Arabia directly. Everything changed with the victory of the Iranian revolution in $1979^{1}$. As a consequence, Ruhollah Khomeini became the main political figure and the spiritual leader, the rahbar, of Iran. He saw himself as "a preeminent religious jurist and became a Marj' $a$, source of emu-

${ }^{1}$ More on the Iranian foreign policy in the Persian Gulf region see: P. Osiewicz (2014), The Iranian Foreign Policy in the Persian Gulf Region Under the Rule of President Hassan Rouhani: Continuity or Change? „Przegląd Strategiczny”, vol. 7. 
lation, for many Shi'i in Iran, Iraq, Lebanon, and elsewhere (Kamrava, 2014, p. 153). According to the Iranian Constitution, the Supreme Leader is the nation's political and spiritual leader who performes his duties during the absence of the hidden Twelfth Imam. Once Mahdi comes back, the Supreme Leader will resign and transfer power to the Imam who will rule the whole world. No doubt it is one of the most important ideological differences between Sunnis and Shia Muslims. Sunnis do not accept such attitude especially as Mahdi is to rule the world just before the Day of Judgment. By the way, some experts expected Iranian authorities to deliberately excacerbate the situation in the region in order to create chaos and turmoil necessary for the Mahdi's return especially during the presidency of Mahmoud Ahmadinejad between 2005-2013 (Gold, 2009, pp. 209-218). At that time a successful nuclear program would have made such scenario very probable. For this reason, since 1979 Saudi authorities have been afraid of a potential negative influence of the Iranian ideology on Shia communities in the region, including the Shia minority in Saudi Arabia. Khomeini called all Muslims "to cast away the disuniters, such as the mercenary akhunds and the nationalists who know nothing of Islam and of the interests of Muslims" (Khalili, Manari, 2000, p. 466) ${ }^{2}$. Moreover, in his opinion the idea of monarchy was in breach of Islamic law and such claims must have posed an indirect ideological threat to Saudi rulers. Yet this concept was not the most dangerous one.

Henner Fürtig rightly points out that Imam Khomeini ,outlined what became the defining credo of early Iranian foreign policy: export of the revolution, namely Sudur-e Enqelab". In his eyes, ,the revolution was not exclusively Shiite. He regarded himself and Iranian Muslims, irrespective of their denomination, as having been chosen by God to reinstate Islam's worldwide significance" (Fürtig, 2014, p. 25). Even if Iran does not promote export of the revolution anymore, it still tries to promote the main principles of the revolution in the Arab world. Moreover, there were various periods in which Iranian authorities were either pragmatic and ready for international cooperation or eager to promote the Shia values and confront with the Arab states in the Middle East. In case of the period between 1997 and 2009, Deshiri claimed that one could observe "the rapprochement of the two idealist and realist approaches" (Deshiri, 2010, p. 5). In the opinion of Rouhollah K. Ramazani there was ,the conundrum of spirituality and pragmatism”, which could be described as ,spiritual pragmatic paradigm” (Ramazani, 2013, p. 196).

In the opinion of Maryam Panah, "the image of the international system painted by Khomeini continued to prevail as and ideological pivot of the regime: the oppression of the Muslim and non-Muslim masses by the dominant powers, the Islamic Republic as the vanguard of the oppressed and their only path to salvation, the illegitimacy of the status quo, and the necessity to establish an Islamic global order" (Panah, 2007, p. 148). As a matter of fact, Iran still underlines the necessity of reforms of the current international system which is unjust and serves interests of the most powerful players especially the United States.

R. K. Ramazani claims that "at the dawn of the Iranian revolution, Ayatollah Ruhollah Khomeini called for 'independence, freedom and the Islamic Republic'. [...] These

2 Akhund (akhoond) is a historical term meaning a spiritual leader in Persia and in Central Asia or just an Islamic cleric, however, iIn Pahlavi Iran (1925-1979), the word came to have a pejorative connotation and in the government-sanctioned press; the term was applied to those who were anachronistic and opposed to modernization" (Akhund, 2015). 
principles are embodied in the Iranian Constitution. Iranian leaders have variously invoked and interpreted them ever since the revolution, and Muhammad Khatami when president designated them as 'eternal' - javidan" (Ramazani, 2011, p. 1). On this basis, by the end of Khatami's presidency, Khamenei outlined the six principles of the Iranian political system including Iran's foreign policy. These principles were:

- isolationism, namely 'Neither East, nor West';

- religious democracy;

- priority of Islamic philosophy in international relations;

- khomeinism especially adherence to vilayat-e faqih, namely the guardianship of the Islamic jurist;

- maintenance of national unity;

- social justice (Hovsepian-Bearce, 2016, p. 206).

No doubt all above-mentioned principles are still valid. Iran's foreign policy is still based on a kind of non-alignment. It is not a member state of any regional international organization except for the Economic Cooperation Organization, position and significance of which are rather disputable. Yet at present the non-alignment is a kind of acceptance of fait accompli rather than a result of any rational choice. International sanctions limited not only Iranian economic relations, but also seriously weakened its diplomatic position. What's more, one can say Iran maintaines good relations neither with Western powers nor with regional actors except for Iraq, Oman, and the Syrian regime.

\section{Divergent Ideological Aspects: Towards Proxy Wars?}

History proves that it is not the first time Iran and Saudi Arabia compete for influence in the region. Moreover, it is not the first time that the Saudi leadership is forced to modify its regional policy. Such situation took place, for example, after 1978. Shah Mohammad Reza Pahlavi lost his power in Iran, two Yemeni states were fighting for supremacy, and Egypt signed a peacy treaty with Israel. In 1985 Nadav Safran dared even to claim that "within less than two years the Kingdom's position and prospects turned from the brightest to the gloomiest in its existence" (Safran, 1985, p. 266). Yet the ongoing conflicts in the region as well as tensions with some other states may result in an even more complex political situation for the Saudi leadership.

The current Saudi-Iranian tensions have resulted in at least two proxy wars, namely in Yemen and Syria. Besides, both sides compete for political influence in other countries, for instance, in Iraq, Bahrain, and Lebanon. Yet the situation in Syria is of the utmost concern to the international community in the world in general and in the region in particular. In view of this, Samer N. Abboud emphasizes the fact that "the increasing presence of foreign actors with presumably sectarian agendas - Saudi Arabia, Qatar, and Iran - gave further meaning to the sectarian logic of the war" (Abboud, 2016). At the very beginning of the conflict, various opposition groups refrained from adopting clear sectarian views. Instead, they articulated a nonsectarian solution with a clear vision of Syria without President Assad. Later they modified their tactics in order to receive financial support from wealthy mecenaries, mainly from the Arab states in the Persian Gulf, including Saudi Arabia, to be able to continue their fight against the regime forces. 
The conflict began as a political tension between President Assad's regime and various opposition groups. The President did not want to end up like dictators in other Arab states, for instance, in Egypt and Libya, and decided to use force in order to defend his power. As a result, the internal situation had aggrevated and had modulated into a full-fledged conflict which was internationalized. Some countries including the Russian Federation and Iran backed Bashar al-Assad while Turkey, most of Western states, and Arab monarchs, including the Saudi king, gave their support to various opposition groups. Among them was not only the Free Syrian Army, but also such radical movements like Jabhat al-Nusra - a Sunni Islamist militia. Its leadership cooperates with jihadist groups and is linked to al-Qaeda.

This way the Syrian conflict has become a kind of proxy war between Sunnis and Shia Muslims in general and between Iran and Saudi Arabia in particular. For this reason various sides in Syria have received support either from Iran, Iraq, and Hezbollah or from the Arab states of the Persian Gulf and Turkey (Micaleff, 2015, p. 47).

„With the increasing cruelty of the Syrian regime and as a sign of conducting a more representative foreign policy to reflect growing public sympathy with the Syrian public, Riyadh's policy developed toward an open and direct attempt to topple the current regime and replace it with a Sunni-led regime friendlier to Saudi Arabia" (Al-Tamamy, 2014, p. 200). However, Yoel Guzansky claims that Saudis have just realized that their hope for a sweeping victory in Syria is illusory. For this reason they count on their current strategy which aim is ,to tip the scales in their favor, bleeding their adversaries financially and militarily" (Guzansky, 2015, p. 52). No doubt among these adversaries in Syria is not only the Assad regime, but also Hezbollah, and Iran. Saudi Arabia supports various Syrian opposition groups hoping to weaken Shiites in the region in general and Iranians in particular. This logic seems to be rational and predictable. The worst for Iran, the better for Saudi Arabia. Even if it equals indirect support for radical Sunni organizations which can ultimately pose a serious threat to the Saudi monarchy too.

It is a well-known fact that Iran and Syria have cooperated for many years. Yet reasons for this cooperation are matters for scholars. Their relations are of strategic, political, and economic nature. Some analysts point to the fact that their alliance began in the 80 's, namely after the Iranian revolution and the establishment of the Islamic Republic of Iran. According to Jubin M. Goodarzi, this alliance has been purely defensive since the very beginning. Moreover, this way Syria and Iran responded to aggressive actions undertaken by Iraq in 1980 and Israel in 1982 (Goodarzi, 2006, p. 33). Besides, both of them intended to counterbalance Turkey in the region. Turkey as an American ally and a NATO member was seen as a source of ideological threat to Syria, a Soviet ally at that time, and the Islamic Republic of Iran. Nowadays both countries still have common foes like the United States, Saudi Arabia, and Israel.

In the opinion of Abbas Maleki, Iran has "hardly a promising background for regional cooperation, either with western allies such as Saudi Arabia, Turkey and Pakistan, or with the small and vulnerable states of the Persian Gulf" (Maleki, 2008, p. 77). It is one of the reasons for Iranian authorities to pay attention to all kind of political developments in Iran's only ally state in the Arab world, namely in Syria. Jean Pierre Filiu adds that Iran supports the Assad regime without clear requirements and expectations (Filiu, 2015, p. 202). 
Interestingly, Iran and Saudi Arabia are accused of supporting of various radical movements and organizations including those designated as terrorist organizations in the United States or in the European Union. In both cases such support is thought to be ideologically motivated. For instance, Iran is often linked with Hezbollah and Hamas while Saudi Arabia is said to maintain indirect relations with wahhabi extremists or even with the so-called Islamic State. The latter is to be supported by some wealthy Saudi citizens with or without acceptance of the House of Saud. Yet the question is which of them could pose a bigger threat to Western values and interests. In the opinion of Stephen Schwartz, "Iran is more concerned with the development of its Islamic model of governance than with international troublemaking, while Saudi Arabia, which was able to assume such a posture at the end of the 1920 s, when the Saudi Ikhwan were repressed, cannot today divorce itself from worldwide Wahhabi extremism" (Schwartz, 2003, p. 306). As far as ideological differences are concerned, the Iranian help for Sunni Hamas proves that sometimes common interests are more important than sectarian division lines. In this case support for oppressed nations in general and for Palestinians in particular remain key elements of the Iranian foreign policy as well as of Iran's official ideology. Iranians tend to see themselves as an oppressed nation too.

Last but not least, the establisment of Da'esh, a radical Sunni organization, was dangerous to all Shia Muslims in general and to Iran in particular. The so-called Islamic State has posed a deadly threat to Iran especially since its successful military campaign in Iraq of 2014. The seizure of Mosul, the second biggest Iraqi city, was a clear warning for Iran. For this reason Iranian authorities have no choice but to deter and fight against the ISIS jihadists. As Olivier Hanne and Thomas Flichy de La Neuville point out, Iranians believe that Da'esh was created by takfiris and armed by the United States through Saudi Arabia in order to destabilize the Assad regime, divide Iraq, and take control over its oil (Hanne, Flichy de La Neuville, 2015, p. 145). Unfortunately, they also link Saudi Arabia to ISIS' actions in Syria and Iraq what can only worsen the current state of Saudi-Iranian affairs. There are even suggestions that if Saudi Arabia and other Gulf states sent their ground troops to Syria, they would officially do that in order to fight ISIS, but in reality their real aim would be to back anti-Assad rebels (Assad on, 2016). And simultaneously undermine Iran's position in this Arab state.

\section{Conclusions}

Undoubtedly, Saudi Arabia and Iran compete for influence in the contemporary Middle East. Their foreign policies are based on divergent principles and their aims are mutually exclusive. Ideology plays a vital role in both countries, however, it does not mean that their leaders do not make rational choices based on political calculations. Both the current Supreme Leader in Iran and the Saudi King have the last say on all important political matters. Yet only the Iranian system is based on an assumption that a supreme leader is at the same time the nation's spiritual leader who performes his duties during the absence of the hidden Twelfth Imam. As a result, his political position is metaphysical.

The current Saudi-Iranian relations are characterized by lack of trust and good will. This mutually negative approach must lead to misunderstandings and ultimately serious 
tensions between both states. Moreover, their divergent ideological attitudes must have resulted in disputes as well as proxy wars in the region. The ongoing military conflicts in Yemen and Syria are probably the best examples. One should also emphasize the fact that both Saudis and Iranians have already competed for political influence in other countries of the region, for instance, in Bahrain, Lebanon, Iraq, and Egypt. As a matter of fact, the 2013 coup d'état in Egypt was backed by Saudi Arabia in order to remove from power the Egyptian Muslim Brotherhood which tried to cooperate with Iranians.

In addition to that, the ideological differences between Iran and Saudi Arabia could pose more serious threats if one or both of them acquired nuclear weapons. Radoslaw Fiedler quite rightly points out that if Iran was possessed of a nuclear bomb, the international community would witness a regional arms race, but this time with nuclear weapons. Such scenario could resemble the rivalry between the United States and the Soviet Union in the Cold War era (Fiedler, 2013, p. 101). Matthew Kroenig claims that ,a nuclear Iran would increase the risk of nuclear proliferation to other states and terrorist groups" (Kroenig, 2014, p. 113). For this reason the P5+1 deal with Iran of 2015 was not the best solution from the Saudi perspective. Saudis do not believe in a good will of the Iranian authorities and claim that Tehran intends to pursue its nuclear program. "The Saudis feel that Tehran and Moscow are undermining Saudi interests at every turn - and that Riyadh's longtime ally, Washington, is doing nothing about it, ostensibly to avoid endangering the prized nuclear deal" (Ghattas, 2016). There is no doubt that the current "dilution of trust between Riyadh and Washington" satisfies Iran and is in line with its regional strategy (Keynoush, 2016, p. 217).

\section{Bibliography}

Abboud S. N. (2016), Syria, Cambridge.

Akbarzadeh S., Conduit D. (2016), Rouhani's First Two Years in Office, in: Iran in the World: President Rouhani's Foreign Policy, eds. S. Akbarzadeh, D. Conduit, Basingstoke.

Akhund (2015), http://www.islamopediaonline.org/glossary/akhund.

Al Faisal T. (2013), Saudi Arabia's Foreign Policy, "Middle East Policy”, vol. 20, no. 4.

Al-Tamamy S. M. (2014), Saudi Arabia and the Arab Spring, in: Regional Powers in the Middle East: New Constellations after the Arab Revolts, ed. H. Fürtig, Basingstoke.

Assad on the offensive, "The Economist", February 13th 2016.

Deshiri M. R., Majidi M. R. (2009), Iran's Foreign Policy in Post-Revolution Era: A Holistic Approach, "The Iranian Journal of International Affairs", vol. 21, no.1-2.

Fiedler R. (2013), Iran a reżim nieproliferacji broni jadrowej. Dylematy i wyzwania, Poznań.

Filiu J. P. (2015), From Deep State to Islamic State: the Arab Counter-Revolution and Its Jihadi Legacy, London.

Djalili M. R., Kellner T. (2015), The Rise of Iran in the Middle East: Between Fiction and Reality, "Turkish Review", vol. 5, no. 5.

Fürtig H. (2014), Iran: Winner or Loser of the “Arab Spring”, in: Regional Powers in the Middle East: New Constellations after the Arab Revolts, ed. H. Fürtig, Basingstoke.

Ghattas K. (2016), The Saudi-Iran War is America's Fault, "Foreign Policy", 13.01.2016.

Gold D. (2009), The Rise of Nuclear Iran: How Tehran Defies the West, Washington D.C.

Goodarzi J. M. (2006), Syria and Iran: Diplomatic Alliance and Power Politics in the Middle East, London. 
Guzansky Y. (2015), The Arab Gulf States and Reform in the Middle East: Between Iran and the "Arab Spring", New York.

Hanne O., Flichy de La Neuville T. (2015), Państwo Islamskie. Geneza nowego kalifatu, Warszawa.

Hovsepian-Bearce Y. (2016), The Political Ideology of Ayatollah Khamenei: Out of the Mouth of the Supreme Leader of Iran, New York.

Kamrava M. (2014), Khomeini and the West, in: A Critical Introduction to Khomeini, ed. A. Adib-Moghaddam, Cambridge.

Keynoush B. (2016), Saudi Arabia and Iran: Friends or Foes?, Basingstoke.

Khalili M. J., Anari S. M. (2000), Fundamentals of the Islamic Revolution: Selections from the Thoughts and Opinions of Imam Khomeini, Tehran.

Kroenig M. (2014), A Time to Attack: The Looming Iranian Nuclear Threat, New York.

Lacey R. (2009), Inside the Kingdom: Kings, Clerics, Modernists, Terrorists, and the Struggle for Saudi Arabia, London.

Landsford T. (2009), Foreign Policies, in: Saudi Arabia and the Gulf Arab States Today: An Encyclopedia of Life in the Arab States, vol. 1, S. Maisel, J. A. Shoup, Westport.

Lawrence R. (2014), Islam in the Balance: Ideational Threats in Arab Politics, Stanford 2014.

Mabon S. (2013), Saudi Arabia \& Iran: Soft Power Rivalry in the Middle East, London.

Maleki A. (2008), Regionalism in Iran's Foreign Policy, in: Reading in Iran Foreign Policy After September 11, eds. A. Maleki, K. Afrasiabi, Lexington.

Małachowski G. (2011), System konstytucyjny Arabii Saudyjskiej, Warszawa.

Micallef J. V. (2015), Islamic State: Its History, Ideology \& Challenge, Vancouver.

Ministry's Vision (2016), http://www.mofa.gov.sa/sites/mofaen/aboutMinistry/vision/Pages/default. aspx, 23.02.2016.

Osiewicz P. (2014), The Iranian Foreign Policy in the Persian Gulf Region Under the Rule of President Hassan Rouhani: Continuity or Change? „Przegląd Strategiczny”, vol. 7.

Panah M. (2007), The Islamic Republic and the World: Global Dimensions of the Iranian Revolution, London.

Ramazani R. K. (2011), Iran's Foreign Policy: Independence, Freedom and the Islamic Republic, in: Iran's Foreign Policy from Khatami to Ahmadinejad, eds. A. Ehteshami, M. Zweiri, Reading.

Ramazani R. K. (2010), Reflections on Iran's Foreign Policy, "Iranian Review of Foreign Affairs", vol. 1 , no. 1.

Safran N. (1985), Saudi Arabia: The Ceaseless Quest for Security, London-Cambridge.

Schwartz S. (2003), The Two Faces of Islam: Saudi Fundamentalism and Its Role in Terrorism, New York 2003.

Teitelbaum J. (2005), The Next Generation of Saudi Ulama: A New Pillar of Support for the Regime?, in: The Middle East: The Impact of Generational Change, Tel Aviv.

Wright S. (2011), Foreign policy in the GCC States, in: International Politics of the Persian Gulf, ed. M. Kamrava, New York.

\section{Ideologiczne uwarunkowania irańsko-saudyjskiej rywalizacji w regionie Bliskiego Wschodu}

\section{Streszczenie}

W styczniu 2016 roku miały miejsce niebezpieczne napięcia w stosunkach irańsko-saudyjskich. Bez wątpienia zarówno Iran, jak i Arabia Saudyjska reprezentują dwa odmienne systemy polityczne i dwa różne podejścia w kwestii formułowania celów polityki zagranicznej. Ważkie z badawczego 
punktu widzenia wydaje się wyjaśnienie przyczyn takiego stanu rzeczy, skoro podstawę obu systemów stanowią wartości islamu.

Głównym celem niniejszego artykułu jest wskazanie najważniejszych ideologicznych różnic pomiędzy Iranem a Arabią Saudyjska, które mają bezpośredni lub tylko pośredni wpływ na prowadzoną przez nie politykę zagraniczną. Główne pytanie badawcze dotyczy z kolei ich możliwego wpływu na obecny stan stosunków na linii Iran-Arabia Saudyjska. Podstawę źródłową artykułu stanowią oficjalne dokumenty, opublikowane przez ministerstwa spraw zagranicznych obu państw, jak również wybrane monografie i artykuły naukowe.

Slowa kluczowe: Iran, Arabia Saudyjska, wojna w Syrii, ideologia religijna, Państwo Islamskie 
